\title{
AKIBAT HUKUM TERHADAP PELANGGARAN RAHASIA DAGANG PADA INDUSTRI PANGAN
}

\author{
Elly Nurhayati (1) \\ ellynoerhayati05@gmail.com ${ }^{(1)}$
}

\section{Universitas Pendidikan Nasional}

\begin{abstract}
The Trade Secrets Act and the Prohibition of Monopolistic Practices and Unfair Business Competition Act do not explicitly contain the legal obligations for workers and former workers to maintain trade secrets. The obligation to maintain confidentiality arises because of the legal relationship between one party and another party. This research discusses about what are the legal consequences of violating trade secrets in the food industry? This research is a normative legal research in which there are no rules regarding the legal obligations of workers and former workers in protecting trade secrets in the food industry, both in the processing of food and beverage industries. The legal impact on violations of trade secrets in the food industry causes harm to owners or holders of trade secrets and unfair business competition.
\end{abstract}

Keywords: legal consequences, trade secrets, food industry

\section{ABSTRAK}

Undang-Undang Rahasia Dagang dan Undang-Undang Larangan Praktik Monopoli dan Persaingan Usaha Tidak Sehat tidak secara eksplisit memuat kewajiban hukum bagi pekerja dan mantan pekerja untuk menjaga rahasia dagang. Kewajiban untuk menjaga kerahasiaan muncul karena adanya hubungan hukum antara satu pihak dengan pihak lainnya. Penelitian ini membahas tentang apa saja akibat hukum dari pelanggaran rahasia dagang di industri makanan? Penelitian ini merupakan penelitian hukum normatif dimana tidak terdapat aturan mengenai kewajiban hukum pekerja dan mantan pekerja dalam melindungi rahasia dagang di industri makanan, baik dalam industri pengolahan makanan dan minuman. Dampak hukum terhadap pelanggaran rahasia dagang di industri makanan menimbulkan kerugian bagi pemilik atau pemegang rahasia dagang dan persaingan usaha tidak sehat.

Kata Kunci: konsekuensi hukum, rahasia dagang, industri makanan

\section{PENDAHULUAN}

Rahasia dagang merupakan salah satu bagian dari hak kekayaan intelektual yang banyak dilanggar di Indonesia. Rahasia dagang menjadi hak kekayaan intelektual karena merupakan suatu hasil pemikiran yang memiliki nilai ekonomi. Secara historis, pengaturan rahasia dagang di Indonesia dimulai sejak Indonesia meratifikasi Agreement Establishing the World Trade Organization (AE WTO) yang mencakup Persetujuan TRIPs. Perjanjian internasional tersebut diratifikasi melalui Undang- undang Nomor 7 Tahun 1994 Tentang Pengesahan Agreement Establishing The World 
Trade Organization. Konsekuensi dari keikutsertaan Indonesia dalam perjanjian internasional tersebut adalah pengaturan Rahasia dalam Undang-Undang Republik Indonesia Nomor 30 Tahun 2000 tentang Rahasia Dagang (selanjutnya disebut UU Rahasia Dagang)). Pengaturan rahasia dagang dalam UU Rahasia Dagang merupakan kewajiban hukum bagi Indonesia yang telah meratifikasi AE WTO termasuk TRIPs dengan Undang-undang Nomor 7 Tahun 1994.

Perkembangan globalisasi perdagangan berimplikasi pada perkembangan pada industri pangan yang semakin lama semakin mengalami peningkatan. Berbagai jenis makanan dan minuman dijual baik secara langsung maupun melalui pemesanan di dunia maya. Hasil olahan dalam industri pangan memiliki cita rasa tersendiri yang dibuat melalui resep tertentu. Resep dibuat oleh pemiliknya melalui hasil pemikiran yang bernilai yang merupakan suatu hak kekayaan intelektual. Resep pada industri pangan merupakan suatu rahasia dagang pemiliknya atau pemegang rahasia dagang. Beberapa contoh industri pangan yang dilindungi rahasia dagang diantaranya Coca Cola, Pizza Hut, KFC, dan sebagainya.

Perlindungan rahasia dagang menurut Pasal 2 UU Rahasia Dagang meliputi berbagai metode yakni sejak metode yang digunakan untuk memproduksi, metode pengolahan, metode dalam melakukan penjualan, atau informasi-informasi lain yang memiliki nilai ekonomi pada bidang teknologi dan/atau bisnis, dimana informasi tersebut memiliki kriteria yakni tidak diketahui oleh masyarakat umum. Berdasarkan ketentuan Pasal 2 disebut UU Rahasia Dagang tersebut maka kegiatan dalam industri pangan, baik berupa hasil makanan dan minuman merupakan informasi di bidang bisnis yang memiliki nilai ekonomi yang hanya diketahui oleh pemiliknya. Oleh sebab itu, hasil industri pangan dilindungi dengan rahasia dagang.

Hasil industri pangan dapat dilindungi oleh rahasia dagang apabila memiliki unsur-unsur sebagaimana yang diatur dalam Pasal 3 UU Rahasia Dagang yang sebagai berikut:

1. Informasi tersebut mempunyai nilai ekonomi, bersifat rahasia, dan kerahasiaannya selalu dijaga. 
2. Informasi yang dimaksudkan tidak diketahui publik melainkan hanya diketahui oleh pihak-pihak tertentu saja.

3. Informasi bersifat rahasia sehingga dapat dipakai untuk menjalankan usaha atau kegiatan komersial atau dengan tujuan mendapatkan keuntungan. Dengan demikian informasi tersebut memiliki nilai ekonomi.

4. Pihak yang memiliki atau memegang rahasia dagang sudah melakukan upaya yang patut dan layak untuk melindungi rahasia dagang.

Sehubungan dengan ketentuan dalam Pasal 3 UU Rahasia Dagang, seorang pemilik rahasia dagang wajib menjelaskan dengan komprehensif bahwa informasi itu memiliki nilai komersial, tidak diketahui umum dan memerlukan biaya-biaya untuk menjaga kerahasiaannya. Dalam pembuktian di pengadilan. Pemilik rahasia dagang harus dapat membuktikan adanya pelanggaran rahasia dagang yakni perbuatan mengambil rahasia dagang secara melawan hukum oleh tergugat. Doktrin Hukum Perdata Internasional menyebut perbuatan tidak memperkaya diri dengan cara yang tidak adil sebagai unjust enrichment. ${ }^{1}$

Doktrin unjust enrichment dapat dihubungkan dengan sejumlah ketentuan dalam KUH Perdata yakni Pasal 1365 dan Pasal 1865 KUH Perdata, dimana seseorang yang memang menyebabkan kerugian harus mendapat ganti kerugian dan hal tersebut harus dibuktikan oleh yang mendalilkan. Terkait dengan perlindungan suatu rahasia dagang tersebut, Muhammad Djumhana dan R. Djubaedillah mengatakan suatu rahasia dagang akan mendapatkan perlindungan apabila informasi tersebut bersifat: ${ }^{2}$

1. Informasi tersebut bersifat rahasia dalam arti hanya diketahui oleh pihak tertentu saja, bukan diketahui umum. Oleh sebab itu, pemiliki rahasia dagang memiliki kewajiban untuk membuktikan bahwa informasi yang dimaksud hanya diketahui secara terbatas yakni oleh pihak-pihak tertentu dalam perusahaannya.

1 Sudargo Gautama, 1994, Arbitrase Bank Dunia Tentang Penanaman Modal Asing di Indonesia dan Jurisprudensi Indonesia Dalam Perkara Hukum Perdata, Binacipta, Bandung, h. $1-2$.

${ }^{2}$ Muhammad Djumhana dan R. Djubaedillah, 2014, Hak Milik Intelektual, PT Citra Aditya Bakti, Bandung, h. 354. 
2. Informasi memiliki nilai ekonomi, sehingga informasi yang dimaksud memang benar-benar digunakan untuk kegiatan usaha komersial untuk mendapatkan keuntungan finansial.

3. Pemilik rahasia dagang melakukan upaya-upaya untuk menjaga sifat kerahasiaan informasi yang digunakan dalam kegiatan usahanya tersebut dari pihak-pihak yang kemungkinan dapat menyebabkan kerugian.

4. Pemilik rahasia dagang dalam menjaga rahasia dagang harus melakukan upaya yang layak dan patut, meskipun dalam undangundang tersebut memang tidak dijelaskan lebih lanjut mengenai hal tersebut.

Pemilik rahasia dagang memiliki hak-hak sebagaimana yang diatur dalam Pasal 4 UU Rahasia Dagang. Pasal 4 UU Rahasia Dagang menyatakan sebagai berikut:

a. menggunakan Rahasia Dagang yang dimilikinya untuk kepentingannya sendiri.

b. melarang pihak lain untuk menggunakan Rahasia Dagang, melarang pihak lain untuk mengungkapkan Rahasia Dagang itu kepada pihak ketiga secara tidak sah untuk kepentingan yang bersifat komersial, maupun memberikan Lisensi kepada pihak lain.

Ketentuan dalam Pasal 4 UU Rahasia Dagang memberikan hak istimewa bagi pemilik resep masakan atau minuman untuk menggunakan sendiri resep yang dibuatnya atau memberikan Lisensi atas penggunaan resep miliknya kepada pihak ketiga. Pemilik rahasia dagang juga berhak untuk melarang pihak lain dalam penggunaan Rahasia Dagang miliknya, dan melarang pihak lain untuk mengungkapkan Rahasia Dagang itu kepada pihak ketiga yang bertujuan untuk memenuhi kepentingan komersial. Ketentuan tersebut memberikan perlindungan hukum bagi pemilik resep agar pekerja dan mantan pekerja yang pernah membantu pemilik resep untuk memasak tidak menggunakan resep industri pangan tadi untuk kepentingan komersil baik yang digunakan sendiri atau diberikan kepada kompetitor.

Ketentuan perlindungan rahasia dagang pada industri pangan ditegaskan pula dalam ketentuan Pasal 23 Undang-Undang Republik Indonesia Nomor 5 Tahun 1999 Tentang Larangan Praktek Monopoli dan 
Persaingan Usaha Tidak Sehat (selanjutnya disebut UU Larangan Praktek Monopoli dan Persaingan Usaha Tidak Sehat). Ketentuan tersebut pada dasarnya melarang pelaku usaha untuk bersekongkol dengan pihak lain dalam mendapatkan informasi kegiatan usaha pesaingnya, dimana informasi kegiatan tersebut termasuk dalam klasifikasi rahasia perusahaan. Larangan ini didasarkan pada pemikiran bahwa kegiatan tersebutg dapat menyebabkan persaingan usaha yang tidak sehat.

Pembocoran rahasia dagang pernah terjadi pada kasus pelanggaran rahasia dagang mantan pekerja pabrik kopi CV Bintang Harapan. Sekitar November 2009, terdakwa mengajak karyawan CV Bintang Harapan untuk pindah ke usaha milik terdakwa yakni CV Tiga Berlian. Terdakwa memerintahkan karyawan-karyawannya untuk membuat sistem kerja, metode pengolahan hingga cita rasa yang sama dengan produk kopi yang sama dengan CV Bintang Harapan. Bahkan untuk memasarkan kopi tersebut, CV Tiga Berlian menggunakan jaringan distribusi yang sama dengan CV Bintang Harapan. Perbuatan terdakwa tersebut terbukti secara sah dan meyakinkan telah melakukan tindak pidana 'tanpa hak menggunakan rahasia dagang pihak lain' dan dipidana dengan penjara selama 1 tahun penjara. ${ }^{3}$

Ketentuan dalam UU Rahasia Dagang dan UU Larangan Praktek Monopoli dan Persaingan Usaha Tidak Sehat memang memuat tentang larangan bagi setiap orang untuk membocorkan rahasia dagang untuk kepentingan komersil, namun ketentuan-ketentuan tersebut tidak memuat ketentuan secara ekplisit mengenai kewajiban hukum bagi pekerja dan mantan pekerja untuk menjaga rahasia dagang. Kewajiban untuk menjaga kerahasiaan timbul karena adanya hubungan hukum antara satu pihak dengan pihak lain. Salah satu hubungan yang sering memunculkan kewajiban menjaga rahasia dagang perusahaan adalah hubungan antara majikan dan pegawai. ${ }^{4}$

Berdasarkan latar belakang penelitian di atas, maka dapat dirumuskan permasalahan sebagai berikut:

${ }^{3}$ Andi Saputra, 2018, Bocorkan Rahasia Dagang Racikan Kopi, Hi Pin Dibui, https://news.detik.com/berita/d-4289403/bocorkan-rahasia-dagang-racikan-kopi-hipin-dibui, diakses 29 Mei 2019.

4 Tim Lidsney BA dkk, 2002, Hak Kekayaan Intelektual Suatu Pengantar, PT Alumni, Bandung, h. 252 
1. Bagaimanakah bentuk-bentuk pelanggaran rahasia dagang pada industri pangan?

2. Bagaimana penyelesaian sengketa rahasia dagang?

\section{METODE PENELITIAN}

Jenis penelitian ini adalah penelitian yuridis normatif. Pada penelitian yuridis normatif, hukum dikonsepkan pada peraturan perundang-undangan (peraturan tertulis), kaidah atau norma-norma yang digunakan sebagai pedoman bagi manusia untuk berperilaku. Permasalahan dalam penelitian ini adalah tidak diaturnya secara eksplisit mengenai tidak mengaturnya Undang-undang secara eksplisit kewajiban hukum pekerja dan mantan pekerja dalam melindungi rahasia dagang pada industri pangan, baik dalam pengolahan industri makanan maupun minuman.

Bahan hukum terdiri dari bahan hukum primer, bahan hukum sekunder dan bahan hukum tersier, namun dalam penelitian ini yang digunakan adalah bahan hukum primer dan bahan hukum sekunder. Permasalahan mengenai rahasia dagang dalam industri pangan dan kemungkinan pelanggaran rahasia dagang yang dilakukan oleh pekerja dan mantan pekerja dieksplanasikan secara jelas, kemudian dianalisis secara kualitatif untuk menggambarkan permasalahan yang dibahas yakni tentang rahasia dagang dalam konteks industri pangan. Penyajian dilakukan secara preskriptif (menghasilkan norma preskriptif).

\section{HASIL PENELITIAN DAN PEMBAHASAN}

\section{A. Bentuk-bentuk Pelanggaran Rahasia Dagang pada Industri Pangan.}

Setiap industri pangan pasti memiliki rahasia dagang guna melindungi upaya-upaya yang telah dilakukan dalam memproduksi makanan dan minuman sesuai dengan ciri khasnya serta melindungi keberlangsungan usahanya. Terkait rahasia dagang tersebut, maka pemilik industri pangan wajib melakukan langkah-langkah untuk melindungi rahasia dagang tersebut dari siapa pun termasuk menjamin pekerja dan mantan pekerjanya untuk menjaga rahasia dagang yang dimilikinya. Pemilik dan pemegang rahasia dagang memiliki hak atas rahasia dagang. Menurut Pasal 1 angka 2 UU Rahasia Dagang, yang 
dimaksud dengan Hak Rahasia Dagang merupakan hak atas rahasia dagang, dimana hak tersebut timbul menurut Undang-undang ini.

Ruang lingkup rahasia dagang dalam industri pangan termasuk pada metode untuk memproduksi, metode pengolahan, pemasaran atau informasi lain yang bersifat rahasia dan memiliki nilai ekonomi di bidang makanan dan minuman. Terkait dengan ruang lingkup rahasia dagang dalam industri pangan ini, rahasia dagang juga termasuk resep makanan dan minuman, formula, proses produksi, daftar klien atau rencana pemasaran. Menurut Pasal 4 UU Rahasia Dagang menyebutkan bahwa hak untuk menggunakan sendiri atau memberikan lisensi dimiliki oleh pemilik rahasia dagang.

Pasal 1 angka 4 UU Rahasia Dagang menyatakan lisensi merupakan suatu izin dari pemegang hak rahasia dagang yang diberikan kepada pihak lain, dimana perbuatan pemberian hak tersebut dituangkan dalam perjanjian untuk penikmatan manfaat ekonomi atas suatu rahasia dagang yang diperjanjikan dengan syarat dan waktu sebagaimana yang tertuang dalam perjanjian. Pemilik hak berhak melakukan larangan kepada siapa saja yang membocorkan rahasia dagang, termasuk menggunakan rahasia untuk kepentingan yang bersifat komersial secara melawan hukum.

Terkait dengan pemajuan dan percepatan industri, bentuk dan diundangkannya Undang-undang Rahasia Dagang dalam rangka mencapai tujuan adalah sebagai berikut: ${ }^{5}$

1. Memajukan industri di Indonesia;

2. Menumbuhkan kembangkan invensi-invensi baru yang dapat memajukan industri tersebut;

3. Melindungi kepentingan hukum terhadap invensi, terutama invensi baru;

4. Menjamin kepastian hukum bagi invensi tidak ada pelanggaran terhadap hak Rahasia Dagang miliknya.

Perlindungan rahasia dagang pada industri pangan bertujuan untuk memajukan industri pangan itu sendiri, melindungi kepentingan hukum pemilik rahasia dagang dan menjamin kepastian hukum dalam

${ }^{5}$ H. Adami Chazawi, 2007, Tindak Pidana Hak Atas Kekayaan Intelektual (HAKI), Bayu Media Publishing, Malang, h. 205-206. 
pencegahan terhadap pelanggaran rahasia dagang. Terkait dengan pelanggaran rahasia dagang, dalam UU Rahasia Dagang dinyatakan yang termasuk sebagai pelanggaran rahasia dagang adalah sebagai berikut:

1. Seseorang yang dengan sengaja membuka informasi yang termasuk dalam Rahasia Dagang, melanggar kesepakatan atau tidak melaksanakan kewajiban tertulis atau tidak tertulis yang mewajibkan pihak tersebut untuk menjaga Rahasia Dagang (Pasal 13 UU Rahasia Dagang).

2. Pelanggaran Rahasia Dagang terjadi apabila ada pihak lain yang mendapatkan dan menguasai Rahasia Dagang dalam kekuasaannya dimana perbuatan tersebut bertentangan dengan peraturan perundang-undangan yang berlaku (Pasal 14 UU Rahasia Dagang), misalnya meminta karyawan perusahaan kompetitor untuk memberikan rahasia dagang milik perusahaan dimana karyawan tersebut bekerja dan karyawan yang diajak bekerja sama tersebut diberikan imbalan uang.

Pelanggaran rahasia dagang sebagaimana yang dimaksud dalam Pasal 13 UU Rahasia Dagang terjadi ketika seorang pekerja membocorkan cara-cara dalam memproduksi, mengolah industri pangan, metode penjualan, serta informasi lain yang bernilai ekonomi pada industri pangan. Pelanggaran rahasia dagang sebagaimana dimaksud dalam Pasal 14 UU Rahasia Dagang adalah apabila ada pihak yang memperoleh atau menguasai metode-metode tersebut dengan cara-cara yang bertentangan dengan peraturan perundangundangan.

Pasal 15 UU Rahasia Dagang menentukan pengecualian atas perbuatan sebagaimana yang dimaksud dalam Pasal 13 UU Rahasia Dagang. Perbuatan-perbuatan yang tidak dianggap pelanggaran Rahasia Dagang apabila:

1. Perbuatan yang membuka rahasia dagang untuk kepentingan pertahanan dan keamanan, keselamatan serta kesehatan masyarakat. 
2. Perbuatan berupa rekayasa ulang atas produk yang terlindungi rahasia dagang orang lain demik kepentingan pengembangan produk selanjutnya.

Pelanggaran terhadap rahasia dagang industri pangan merugikan pemilik atau pemegang rahasia dagang. Rahasia dagang dibuat dengan pemikiran ahli yang berlangsung lama, sehingga apabila terjadi pelanggaran rahasia dagang maka akan terjadi kerugian baik secara ekonomi maupun secara moral. Untuk mengurangi resiko pelanggaran rahasia dagang, maka pemilik atau pemegang rahasia dagang harus melakukan upaya untuk mencegah pelanggaran rahasia dagang. Langkah-langkah yang dapat dilakukan untuk menjaga rahasia dagang menurut Iman Sjahputra Tunggal dan Heri Herjandono adalah sebagai berikut: ${ }^{6}$

1. Pengungkapan rahasia dagang secara terbatas yakni hanya kepada orang yang memang benar-benar perlu mengetahui tentang rahasia dagang tersebut.

2. Pembuatan perjanjian tentang kewajiban menjaga rahasia dagang dengan karyawan atau pihak ketiga yang terkait.

3. Penggunaan kode rahasia pada pengungkapan data.

4. Penyimpanan arsip dokumen pada tempat tertentu yang aman, terlindung, atau pada departemen lain di suatu perusahaan.

5. Pencantuman kata "rahasia" pada bagian sampul dokumen.

6. Pembatasan akses bagi karyawan untuk memasuki unit atau departemen selain yang berkepentingan.

7. Larangan bagi karyawan bekerja di luar jam kerja.

Paat dalam jurnal akademik/ ilmiah menyatakan bahwa untuk mempertahankan eksistensi rahasia dagang maka pemiliknya harus melakukan langkah-langkah konkret untuk melindunginya, langkahlangkah itu dapat hal-hal berupa sebagai berikut: ${ }^{7}$

a. Pengungkapan rahasia dagang hanya dilakukan terhadap mereka yang perlu mengetahuinya saja dengan persyaratan-

${ }^{6}$ Ni Made Ayu Darma Pratiwi Agustina, 2014, Perlindungan Hukum Rahasia Dagang Setelah Berakhirnya Perjanjian Kerja, Universitas Atma Jaya, Yogyakarta, h.8.

7 Paat, Y. L., 2013, Penyelesaian Sengketa Rahasia Dagang Menurut Hukum Positif Indonesia, Lex et Societatis, Volume 1 Nomor 3, h. 41. 
persyaratan yang sifatnya rahasia. Dengan demikian pengungkapan rahasia hendaknya hanya dilakukan setelah adanya jaminan misalnya untuk kerjasama antar perusahaan pengungkapan hanya dapat dilakukan setelah perjanjian ditandatangani.

b. Rahasia dagang harus selalu dimasukkan ke dalam kelompok informasi atau data yang bersifat rahasia. Dengan demikian maka seluruh dokumen yang mencantumkan rahasia dagang tersebut harus dibubuhi tanda "rahasia" dan karyawan yang tidak berkepentingan dilarang mengetahui informasi itu.

c. Akses publik terhadap informasi itu dalam berbagai bentuk harus dihindari. Termasuk di dalamnya kegiatan-kegiatan penelitian laboratorium, studi literatur, perbandingan proses produksi dan lain-lain.

d. Dalam perjanjian kerja antara perusahaan dengan karyawan harus diatur secara tegas ketentuan tentang larangan pengungkapan rahasia dagang di luar tugas-tugasnya seperti jika berhubungan dengan pihak lain yang tidak terikat dalam perjanjian.

Para pihak yang terikat untuk menyimpan rahasia dagang wajib melaksanakan perjanjian rahasia dagang tersebut. Lebih lanjut Patricia Loughlan mengatakan apabila pemilik rahasia dagang memberitahukan informasi rahasia dagang kepada pekerja maka informasi tersebut masih bersifat rahasia karena lingkupnya masih ada di lingkungan perusahaan. Sebaliknya apabila rahasia itu diketahui oleh dua orang yang menjadi pesaing dari pemilik rahasia dagang, maka kerahasiaan informasi akan menjadi hilang. ${ }^{8}$

Pihak yang memiliki rahasia dagang wajib melakukan upaya untuk menjamin rahasia dagang. Sebagai contoh, produk Coca-Cola memiliki resep formula pembuatan minuman ini yang tersimpan di The World of Coca-Cola di Atlanta. Manajemen Coca-Cola membatasi orang-orang yang dapat masuk pada rumah penyimpangan tersebut yakni hanya

8 Patricia Loughlan, 1998, Intellectual Property Creative and Marketing Right, LBC Information Service, Sydney, h. 146-147. 
beberapa orang eksekutif saja. $^{9}$

Coca-Cola Amatil Indonesia (CCAI) yang beroperasi pertama kali pada tahun 1992 memiliki Commercial Product Supply Indonesia (CPS) yang terlindung rahasia dagang. The Coca-Cola Company (pemilik merek dagang) menyediakan konsentrat produk-produk Coca-Cola yang disalurkan kepada mitra pembotolan lokal. CCAI memproduksi bahan dasar minuman produk usaha ini yang digunakan untuk pabrik pembotolan dan melakukan pemasaran merek dagang Cocal-Cola di Indonesia. ${ }^{10}$

\section{B. Penyelesaian Sengketa Rahasia Dagang}

Pelanggaran rahasia dagang akan menimbulkan sengketa antara pemilik atau pemegang rahasia dagang dengan pihak yang melanggar rahasia dagang. Menurut Nurnaningsih Amriani, sengketa disebabkan karena adanya peselisihan para pihak akibat dari pelanggaran kontrak, baik pada sebagian atau seluruh isi kontrak. Perbuatan ini merupakan wanprestasi. ${ }^{11}$ Takdir Rahmadi mengatakan bahwa sengketa terjadi karena adanya kepentingan yang tidak sejalan. Para pihak yang bersengketa berada pada kondisi dimana terdapat perbedaan persepsi atau perselisihan. ${ }^{12}$

Sengketa merupakan perselisihan yang disebabkan karena perbedaan persepsi para pihak yang tidak menemukan jalan damai. Sengketa terjadi karena faktor kebutuhan dan kepentingan manusia. Terkait dengan adanya pelanggaran atas rahasia dagang ini, maka pelanggaran rahasia dagang dapat dikaitkan dengan kebutuhan manusia dan kepentingan manusia. Kebutuhan dan kepentingan manusia tersebut menurut Takdir Rahmadi dapat dikelompokkan

9 Lucky Setiawati, Rahasia Dagang dan Perlindungan Formula Resep Makanan,

https://www.hukumonline.com/klinik/detail/ulasan/lt4feadb7627be1/perlindunganresep-kue/, diakses pada 15 Oktober 2019.

${ }^{10}$ Coca-cola Amatil Indonesia, Coca-Cola : Lebih dari 80 Tahun Mengabdi Pada Indonesia, http://coca-colaamatil.co.id/cormobile/pages/index/61, diakses pada 28 November 2019.

11 Nurnaningsih Amriani, 2012, Mediasi Alternatif Penyelesaian Sengketa Perdata di Pengadilan, Raja Grafindo Persada, Jakarta, h. 12.

12 Takdir Rahmadi, 2011, Mediasi Penyelesaian Sengketa Melalui Pendekatan Mufakat, PT. Raja Grafindo Persada, Jakarta, h. 1. 
menjadi susbtantif yakni terkait dengan kebutuhan pokok manusia akan kebendaan dan kekayaan, procedural yakni terkait dengan pergaulan manusia dalam kehidupan bermasyarakat dan psikologis yakni kebutuhan dan kepentingan yang bersifat immateriil misalnya penghargaan dan rasa empati. ${ }^{13}$

Penyelesaian sengketa merupakan bagian yang paling menentukan untuk mengakhiri konflik. Dean G Pruitt dan Jeffrey Z. Rubin mengemukakan sebuah konsep tentang penyelesaian sengketa. Menurut Dean G Pruitt dan Jeffrey Z. Rubin, konsep penyelesaian sengketa ada 5 (lima), yaitu: ${ }^{14}$

a) Contending (bertanding), yaitu penerapan solusi yang berpihak pada salah satu pihak dibandingkan dengan pihak lain.

b) Yielding (mengalah), yaitu bersedia menerima suatu kondisi dengan menurunkan ras ego.

c) Problem solving (pemecahan masalah), yaitu kondisi dimana terdapat alternatif yang memuaskan semua pihak.

d) With drawing (menarik diri), yaitu meninggalkan suatu kondisi sengketa, baik menarik diri secara fisik maupun secara psikologis.

e) In action (diam), yaitu tidak mengambil langkah apa pun.

Terkait dengan konteks hukum, khususnya dalam lapangan hukum perdata, ada dua cara penyelesaian sengketa yakni secara litigasi dan non litigasi. Litigasi yakni penyelesaian sengketa yang dilakukan pada proses pemeriksaan di pengadilan dimana para pihak dapat membuktikan dalilnya masing-masing dihadapan hakim. Produk dari penyelesaian sengketa di pengadilan ini adalah win-lose solution yang dituangkan pada putusan. ${ }^{15}$

Jalur litigasi dilakukan dengan mengajukan gugatan di pengadilan. Berdasarkan pada Pasal 118 ayat (1) HIR pengajuan gugatan perdata diajukan di Pengadilan Negeri berdasarkan kompetensi relatifnyaberdasarkan tempat tinggal tergugat atau domisisli hukum yang ditunjuk berdasarkan kesepakatan. Pengajuan gugatan tertulis dialamtkan

13 Ibid., h. 10.

14 Dean G Pruitt \&Z. Rubin, 2004, Konflik Sosial, Pustaka Pelajar, Yogyakarta, h. 4-6.

${ }^{15}$ Nurnaningsih Amriani, op.cit. h. 35. 
kepada Ketua Pengadilan Negeri dan ditandatangani oleh penggugat. Pendaftaran dilakukan di bagian kepaniteraan dan selanjutnya penggugat diwajibkan membayar biaya perkara (panjar perkara) sebagai biaya awal yang selanjutnya diperhitungkan kembali pasca adanya putusan Pengadilan.

Penyelesaian sengketa rahasia dagang melalui jalur litigasi dapat dilakukan dengan gugatan wanprestasi atau gugatan perbuatan melawan hukum. Dalam Pasal 1234 KUH Perdata memiliki rasio bahwa 1) perikatan ditujukan untuk memberikan sesuatu, 2) perikatan untuk berbuat sesuatu, atau 3) perikatan untuk tidak berbuat sesuatu." Berdasarkan ketentuan tersebut maka prestasi dapat berupa:

a. Memberikan sesuatu

b. Berbuat sesuatu.

c. Tidak berbuat sesuatu

Pasal 1234 KUH Perdata menyatakan bahwa yang dimaksud dengan prestasi adalah seseorang yang menyerahkan sesuatu, tidak melakukan sesuatu. Prestasi dari perikatan harus memenuhi syarat:

a. Harus diperkenankan, artinya prestasi itu tidak melanggar ketertiban, kesusilaan, dan Undang-undang.

b. Harus tertentu atau dapat ditentukan.

c. Harus memungkinkan untuk dilakukan menurut kemampuan manusia. ${ }^{16}$

Jenis perjanjian yang menimbulkan perikatan hingga di pundak masing-masing pihak mengusung kewajiban tergolong perjanjian obligatoir. ${ }^{17}$ Dalam pelaksanaan perjanjian, dapat terjadi wanprestasi yang berarti tidak memenuhi kewajiban yang telah dituangkan dalam perjanjian. Wanprestasi merupakan suatu kondisi dimana debitu tidak melaksanakan kewajiban (tidak berprestasi) dan debitur tersebut dapat dipersalahkan. ${ }^{18}$ Waprestasi yang menurut Bahasa Belanda "wanprestatie" adalah kondisi dimana kewajiban yang telah ditetapkan dalam perikatan yang timbul dari perjanjian atau Undang-undang tidak

16 Handri Raharjo, 2009, Hukum Perjanjian di Indonesia, Pustaka Yustisia, Yogyakarta, h. 79.

17 Moch. Isnaeni, 2016, Perjanjian Jual Beli, Revka Petra Media, Surabaya, h. 15.

18 Ibid. 
dipenuhi. ${ }^{19}$ Gugatan wanprestasi terjadi ketika antara pemilik dan pemegang rahasia dagang dengan orang yang dikemudian hari melanggar rahasia dagang memiliki perjanjian untuk menjaga rahasia dagang.

Gugatan terhadap pelanggaran rahasia dagang juga dapat dilakukan dengan perbuatan melawan hukum apabila tidak ada perjanjian untuk menjaga rahasia dagang antara penggugat dengan tergugat sebelumnya. Gugatan perbuatan mewalan hukum dilakukan berdasarkan Pasal 1365 KUH Perdata. Dalam Pasal 1365 KUH Perdata selengkapnya mengatakan sebagai berikut:

Perbuatan melawan hukum merupakan setiap perbuatan yang melanggar hukum yang membawa kerugian bagi orang lain, hal mana mewajibkan kepada pihak yang melakukan kesalahan itu memberi ganti kerugian kepada pihak yang dirugikan tersebut. Ketentuan Pasal 1365 KUH Perdata ini pada prinsipnya bertujuan memberikan substansi perdata terhadap semua bentuk pelanggaran yang merugikan pihak lain. ${ }^{20}$ Jika dikaitkan dengan perlindungan asas Rahasia Dagang, maka pihak yang telah melanggar hak-hak atas suatu informasi rahasia yang dimiliki seseorang yang memiliki nilai komersial dapat dikualifikasikan sebagai perbuatan melawan hukum. Ketentuan Pasal KUH Perdata ini pada prinsipnya bertujuan memberikan substansi perdata terhadap semua bentuk pelanggaran yang merugikan pihak lain.

Tujuan gugatan wanprestasi ialah dengan menempatkan posisi penggugat pada posisi apabila perjanjian tersebut terpenuhi. Ganti rugi yang diajukan adalah nilai ekonomi atas hilangnya keuntungan yang diharapkan (expectationloss atau winstderving). Kondisi ini berbeda dengan gugatan pada perbuatan melawan hukum. Gugatan pada perbuatan melawan hukum ini adalah penempatan posisi penggugat kepada keadaan semula, yakni pada posisi sebelum dilakukannya

19 A. Qiram Syamsudin Meliala, 2001, Hukum Perjanjian, Mandar Maju, Yogyakarta, h. 20.

20 Ahmad M. Ramli., 2001, Perlindungan Rahasia Dagang dalam UU No. 30/2000 dan Perbandingan dengan Beberapa Negara, CV. Bandar Maju, Bandung, h. 50 
perbuatan melawan hukum. Ganti rugi pada perbuatan melawan hukum berupa kerugian yang nyata. ${ }^{21}$

Proses penyelesaian sengketa rahasia dagang melalui litigasi dapat dilihat contohnya pada kasus gugatan pelanggaran rahasia dagang dalam Putusan Kasasi Nomor 2535 K/Pdt/2016 dengan penggugat (Budi Djatmiko Sugiarto (Tanyoktjay); dan Meliani Sugiarto). Penggugat adalah pemilik Lunpia Express sesuai dengan Surat Izin Perdagangan (SIUP) Kecil Nomor 2579/1 I.OI/PK/X/2005 tanggal 31 Oktober 2005 juncto menggugat Tuan Soegiyanto Winarso atas kesamaan metode produksi, pengolahan dan pemasaran produk makanan milik penggugat merek "Lunpia Express" dan produk makanan milik para tergugat merek "Lunpia Delight."

Penyelesaian sengketa melalui pengadilan sedikit demi sedikit mulai ditinggalkan oleh pihak yang berperkara. Mereka beralih pada penyelesaian sengketa di luar pengadilan atau alternative dispute resolution $(A D R)$. Penyelesaian sengketa non litigasi didasarkan pada Undang-Undang Nomor 30 tahun 1999 tentang Arbitrase dan Alternatif Penyelesaian Sengketa (selanjutnya disebut UU Arbitrase). Nurnaningsih Amriani selanjutnya menyatakan sebagai berikut:

Pada dasarnya penyelesaian sengketa dapat dilakukan dengan dua pilihan jalur yakni penyelesaian sengketa secara litigasi dan non litigasi. Penyelesaian sengketa litigasi dilakukan dengan mengajukan gugatan ke pengadilan. Penyelesaian sengketa secara non litigasi terdiri atas berbagai macam cara yakni konsultasi (consultation), negosiasi (negotiation), mediasi (mediation), konsiliasi (conciliation), dan penilai ahli. $^{22}$

Untuk mengetahui objek perkara yang dapat diselesaikan melalui ADR maka dapat dianalisis melalui beberapa ketentuan dalam UU Arbitrase. Pada dasar menimbang dapat diketahui bahwa penyelesaian perkara perdata dapat diajukan ke peradilan umum maupun melalui arbitrase dan alternatif penyelesaian sengketa." Selanjutnya dalam Pasal 2 UU Arbitrase dapat diketahui bahwa penyelesaian beda

${ }_{21}$ Suharnoko, 2014, Hukum Perjanjian Teori dan Analisis Kasus, Kencana, Jakarta, h. 115-116.

22 Rachmadi Usman, 2012, Mediasi di Pengadilan Dalam Teori dan Praktik, Sinar Grafika, Jakarta, h. 10. 
pendapat dan sengketa antara para pihak yang telah mengadakan perjanjian arbitrase harus menyelesaikan sengketa atau beda pendapat melalui cara arbitrase atau melalui alternatif penyelesaian sengketa.

Pasal 5 ayat (1) UU Arbitrase menyebutkan bahwa penyelesaian sengketa melalui arbitrase adalah sengketa yang terjadi pada bidang perdagangan, sengketa yang timbul dari adanya hak yang menurut hukum dan peraturan perundang-undangan yang penguasaannya sepenuhnya oleh pihak yang bersengketa. Pasal 6 ayat (1) UU Arbitrase mengedepankan itikad baik dalam penyelesaian sengketa dan beda pedapat di luar pengadilan. Para pihak pada dasarnya bebas untuk memilih model penyelesaian secara non litigasi tergantung dari kesepakatan para pihak.

Pelanggaran rahasia dagang merupakan pelanggaran dalam bidang bisnis, sehingga dibutuhkan penyelesaian perkara secara cepat, biaya yang murah dan sederhana. Kondisi tersebut menyebabkan penyelesaian sengketa secara non litigasi lebih memenuhi kebutuhan para pebisnis yakni pemilik atau pemegang rahasia dagang, dimana penyelesaian sengketa harus diselesaikan secepat dan sesederhana mungkin. Penyelesaian sengketa secara non litigasi ini juga menjamin privasi dari para pihak yang bersengketa.

\section{KESIMPULAN}

Akibat hukum terhadap pelanggaran rahasia dagang pada industri pangan menyebabkan kerugian bagi pemilik industri pangan. Kerugian tersebut disebabkan karena wanprestasi yang dilakukan pekerja atau mantan pekerja terhadap kewajiban menjaga rahasia dagang, pengambilan rahasia dagang dengan cara-cara melawan hukum, dan pemanfaatan rahasia dagang tanpa hak. Penyelesaian sengketa terhadap pelanggaran rahasia dagang dapat ditempuh melalui jalur litigasi dan non litigasi. Namun, sebagaian besar penyelesaian dilakukan dengan jalur litigasi. Pelaku pelanggaran rahasia dagang dapat juga dijatuhi sanksi pidana sebagaimana yang diatur dalam Pasal 17 UU Rahasia Dagang.

Pemberi kerja sebagai pemegang rahasia dagang sebaiknya menuangkan kewajiban untuk menjaga rahasia dagang dalam perjanjian kerja yang berbentuk tertulis. Kewajiban tersebut mengikat bagi pekerja 
baik yang masih terikat perjanjian kerja maupun yang sudah tidak lagi terikat perjanjian kerja dengan pengusaha industri pangan. Pemberi kerja hendaknya melakukan sosialisasi akan klausul menjaga rahasia dagang bagi pekerja dalam perjanjian kerja antara pemberi kerja dengan pekerja. Pekerja dan mantan pekerja industri pangan hendaknya tidak membocorkan atau menggunakan untuk kepentingan ekonomi rahasia dagang yang telah diketahuinya.

\section{DAFTAR PUSTAKA}

Buku:

Agustina, Ni Made Ayu Darma Pratiwi, 2014, Perlindungan Hukum Rahasia Dagang Setelah Berakhirnya Perjanjian Kerja, Universitas Atma Jaya, Yogyakarta.

Amiruddin dan H. Zainal Asikin, 2006, Pengantar Metode Penelitian Hukum, RajaGrafindo Persada, Jakarta.

Amriani, Nurnaningsih 2012, Mediasi Alternatif Penyelesaian Sengketa Perdata di Pengadilan, Raja Grafindo Persada, Jakarta.

Chazawi H., Adami, 2007, Tindak Pidana Hak Atas Kekayaan Intelektual (HAKI), Bayu Media Publishing, Malang.

Djumhana, Muhammad dan R. Djubaedillah, 2014, Hak Milik Intelektual, PT Citra Aditya Bakti, Bandung.

Gautama, Sudargo, 1994, Arbitrase Bank Dunia Tentang Penanaman Modal Asing di Indonesia dan Jurisprudensi Indonesia Dalam Perkara Hukum Perdata, Binacipta, Bandung.

Isnaeni, Moch. 2016, Perjanjian Jual Beli, Revka Petra Media, Surabaya.

Lidsney, Tim BA dkk, 2002, Hak Kekayaan Intelektual Suatu Pengantar, PT Alumni, Bandung.

Loughlan, Patricia, 1998, Intellectual Property Creative and Marketing Right, LBC Information Service, Sydney.

Meliala, A. Qiram Syamsudin, 2001, Hukum Perjanjian, Mandar Maju, Yogyakarta.

Pruitt, Dean G \&Z. Rubin, 2004, Konflik Sosial, Pustaka Pelajar, Yogyakarta.

Raharjo, Handri, 2009, Hukum Perjanjian di Indonesia, Pustaka Yustisia, Yogyakarta.

Rahmadi, Takdir 2011, Mediasi Penyelesaian Sengketa Melalui Pendekatan Mufakat, PT. Raja Grafindo Persada, Jakarta.

Ramli., Ahmad M., 2001, Perlindungan Rahasia Dagang dalam UU No. 30/2000 dan Perbandingan dengan Beberapa Negara, CV. Bandar Maju, Bandung,

Suharnoko, 2014, Hukum Perjanjian Teori dan Analisis Kasus, Kencana, Jakarta.

Usman, Rachmadi, 2012, Mediasi di Pengadilan Dalam Teori dan Praktik, Sinar Grafika, Jakarta.

Jurnal :

Paat, Y. L., 2013, Penyelesaian Sengketa Rahasia Dagang Menurut 
Hukum Positif Indonesia, Lex et Societatis, Volume 1 Nomor 3.

\section{Peraturan Perundang-Undangan}

Undang-undang Nomor 7 Tahun 1994 Tentang Pengesahan Agreement Establishing The World Trade Organization (Persetujuan Pembentukan Organisasi Perdagangan Dunia). (Lembaran Negara Republik Indonesia Tahun 1994 Nomor 57, Tambahan Lembaran Negara Republik Indonesia Nomor 3564).

Undang-Undang Republik Indonesia Nomor 5 Tahun 1999 Tentang Larangan Praktek Monopoli dan Persaingan Usaha Tidak Sehat. (Lembaran Negara Republik Indonesia Tahun 1999 Nomor 33, Tambahan Lembaran Negara Republik Indonesia Nomor 3817).

Undang-Undang Republik Indonesia Nomor 30 Tahun 2000 tentang Rahasia Dagang. (Lembaran Negara Republik Indonesia Tahun 2000 Nomor 242, Tambahan Lembaran Negara Republik Indonesia Nomor 4044).

Undang-undang Republik Indonesia Nomor 13 Tahun 2003 tentang Ketenagakerjaan. (Lembaran Negara Republik Indonesia Tahun 2003 Nomor 39, Tambahan Lembaran Negara Republik Indonesia Nomor 4279).

Undang-Undang Republik Indonesia Nomor 18 Tahun 2012 Tentang Pangan. (Lembaran Negara Republik Indonesia Tahun 2012 Nomor 227, Tambahan Lembaran Negara Republik Indonesia Nomor 5360).

Undang-Undang Republik Indonesia Nomor 3 Tahun 2014 Tentang Perindustrian (Lembaran Negara Republik Indonesia Tahun 2014 Nomor 4, Tambahan Lembaran Negara Republik Indonesia Nomor 5492).

\section{Internet}

Coca-cola Amatil Indonesia, Coca-Cola : Lebih dari 80 Tahun Mengabdi Pada Indonesia, http://cocacolaamatil.co.id/cormobile/pages/index/61, diakses pada 28 November 2019.

Saputra, Andi, 2018, Bocorkan Rahasia Dagang Racikan Kopi, Hi Pin Dibui, $\quad$ https://news.detik.com/berita/d-4289403/bocorkan-rahasiadagang-racikan-kopi-hi-pin-dibui, diakses 29 Mei 2019.

Setiawati, Lucky, Rahasia Dagang dan Perlindungan Formula Resep Makanan, https://www.hukumonline.com/klinik/detail/ulasan/tt4feadb7627be1/pe rlindungan-resep-kue/, diakses pada 15 Oktober 2019 